\title{
Innovative Instruments of Monetary and Fiscal Policy
}

\author{
Bohdan Danylyshyn ${ }^{1}$, Maksym Dubyna ${ }^{2}$, Maksym Zabashtanskyi ${ }^{3}$, Natalia Ostrovska ${ }^{4}$, \\ Kateryna Blishchuk ${ }^{5, *}$, Ivanna Kozak ${ }^{5}$ \\ ${ }^{1}$ Department of Regional Studies and Tourism, Kyiv National Economic University named after Vadym Hetman, Kyiv, Ukraine \\ ${ }^{2}$ Department of Finance, Banking and Insurance, National University "Chernihiv Polytechnic", Chernihiv, Ukraine \\ ${ }^{3}$ Educational-Scientific Institute of Business, Environmental Management and Tourism, National University "Chernihiv Polytechnic", \\ Chernihiv, Ukraine \\ ${ }^{4}$ Department of Public, Corporate Finances and Financial Intermediation, Yuriy Fedkovych Chernivtsi National University, \\ Chernivtsi, Ukraine \\ ${ }^{5}$ Department of Economy, Lviv Regional Institute for Public Administration of the National Academy for Public Administration \\ under the President of Ukraine, Lviv-Briukhovychi, Ukraine
}

Received August 11, 2021; Revised September 15, 2021; Accepted October 15, 2021

\section{Cite This Paper in the following Citation Styles}

(a): [1] Bohdan Danylyshyn, Maksym Dubyna, Maksym Zabashtanskyi, Natalia Ostrovska, Kateryna Blishchuk, Ivanna Kozak, "Innovative Instruments of Monetary and Fiscal Policy," Universal Journal of Accounting and Finance, Vol. 9, No. 6, pp. 1213 - 1221, 2021. DOI: 10.13189/ujaf.2021.090601.

(b): Bohdan Danylyshyn, Maksym Dubyna, Maksym Zabashtanskyi, Natalia Ostrovska, Kateryna Blishchuk, Ivanna Kozak (2021). Innovative Instruments of Monetary and Fiscal Policy. Universal Journal of Accounting and Finance, 9(6), 1213 - 1221. DOI: 10.13189/ujaf.2021.090601.

Copyright $\bigcirc 2021$ by authors, all rights reserved. Authors agree that this article remains permanently open access under the terms of the Creative Commons Attribution License 4.0 International License

\begin{abstract}
Any economic system can be identified as cyclical fluctuations: ups and downs in the economy, which are caused by shocks of aggregate demand and aggregate supply and called business cycles, economic or business cycles. The phases of business cycles are the rise, "peak", recession (or decline) and "bottom", i.e. the crisis. Often such fluctuations in business activity are unpredictable and irregular. At the present stage of development, the state of Ukraine is unstable and characterized by significant crisis processes and phenomena, including critical growth of debt, devaluation of the national currency and limited reserves of the National Bank, reduced lending by banks to the real sector, low financial stability and more. These challenges are exacerbated by the impact of modern global external factors destabilizing financial systems at various levels and financial and economic relations, including the COVID-19 pandemic, which raises the issue of justifying the development and implementation of effective innovative monetary and fiscal policy instruments. The authors explored the nature, components and objectives of monetary and fiscal policy. The authors analyzed the challenges of stabilizing the monetary sector and fiscal policy and developed improving tools. The authors proposed an algorithm for assessing the effectiveness of the monetary policy, where the main criteria for the
\end{abstract}

effectiveness of monetary policy are the criteria that contribute to macroeconomic stability. Regarding innovative fiscal policy instruments, the authors proposed to provide targeted support for industries or projects, namely, the algorithm for determining targeted support for sectors, which implies the creation of clusters of industries and considers the possible negative consequences of the COVID-19 pandemic. The proposed instruments will allow stabilizing the economy to a greater extent, as well as to ensuring more excellent price stability, maintaining a stable exchange rate and promoting balanced economic growth.

Keywords Cluster, Economic Cyclical Fluctuations, Financial Relations, Fiscal Instruments, Fiscal Policy, Monetary Policy

\section{Introduction}

At the present stage of development, the state of Ukraine is unstable and characterized by significant crisis processes and phenomena, including critical growth of debt, devaluation of the national currency and limited reserves of the National Bank, reduced lending by banks to the real 
sector, low financial stability and more [1; 2]. The coronavirus pandemic is pushing the Ukrainian economy into the worst recession in decades [3].

These trends are primarily due to the negative aspects of the functioning of the monetary sphere of the state, where the essential functions of supporting macroeconomic and financial stability, economic growth and competitiveness of the national economy are insufficient, increasing threats to financial security, such as critical growth settlement crises, inflation, depreciation and fluctuations in the value of the national currency, increasing the level and narrowing of sources of public debt financing, increasing risks of default, the decline of the banking, insurance and stock sectors of the financial system.

Monetary and fiscal policy in the state is conducted with the help of its instruments $[4 ; 5]$. Analyzing the decisions on monetary policy in 2020 and their impact on macroeconomic, including inflationary processes in the country, we can conclude that price stability in Ukraine in the definition of the Law has not been achieved. At the same time, the monetary policy of the National Bank last year did not contribute to financial stability and stable economic growth [6]. State instruments are economic mechanisms by which the goals set before the monetary and fiscal policy are achieved, so the article aims to develop new monetary and fiscal policy instruments.

\section{Theoretically-Analytical Basis}

Monetary (monetary or monetary) policy is the macroeconomic policy of the monetary authorities, a set of measures aimed at managing aggregate demand through money market conditions (short-term interest rate, nominal exchange rate or the level of current liquidity of the banking sector) to achieve a combination of ultimate goals which may include price stability, maintaining a stable exchange rate, financial stability and promoting balanced economic growth.

Monetary policy is represented by such main categories (Fig. 1).

The principles of monetary policy, namely, the fundamental rules and regulations of policy of the central bank that are binding, include [7]:

- $\quad$ selection of an explicit nominal monetary policy anchor;

- $\quad$ economic and political independence of the central bank;

- $\quad$ responsibility and accountability of the central bank to the public;

- information openness (transparency) of monetary policy.

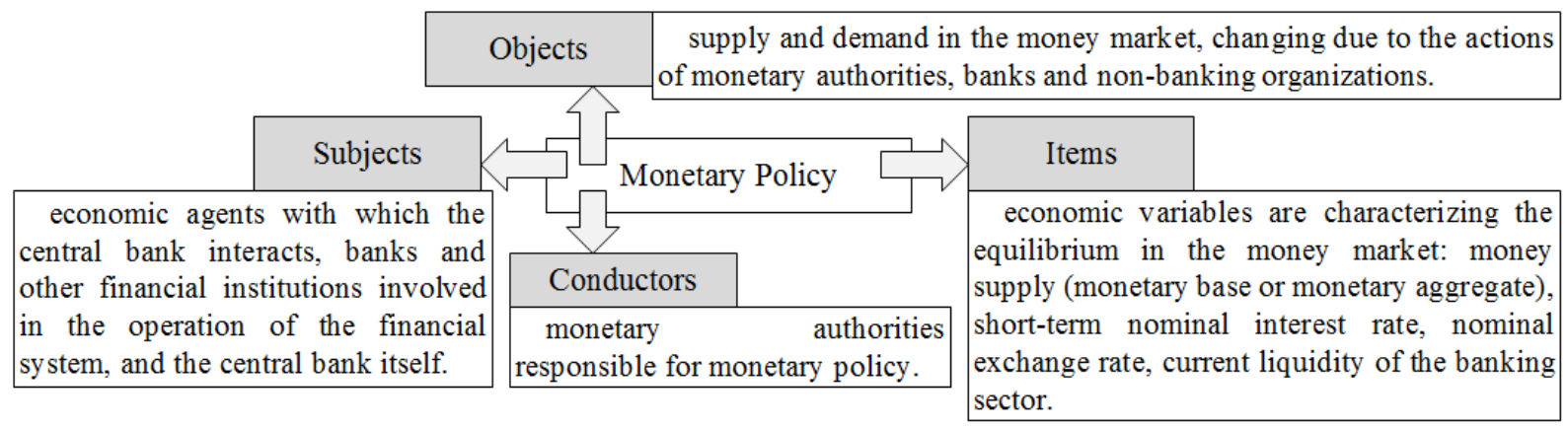

Figure 1. Categories of monetary policy 
At the Bundesbank conference in 2007, the American economist Frederic Mishkin voiced nine theses that formed the theoretical foundations of monetary policy and suggested calling them "basic scientific principles of monetary policy" [8]:

- inflation is always and everywhere a monetary phenomenon: expansionary monetary policy can be the cause of inflation,

- $\quad$ rice stability brings with it significant economic benefits: central banks can manage inflation and must keep it low and sustainable,

- in the long run, there is no choice between unemployment and inflation: monetary policy should not aim for low unemployment, as this leads to higher inflation,

- expectations play an essential role in macroeconomics: managing expectations should be central to monetary policy,

- to maintain price stability, it is necessary to adhere to the "Taylor principle": low inflation will be stable if the nominal interest rate increases by a more significant amount than the growing inflation, which will allow the real interest rate to be raised in response to the rise in inflation,

- it is necessary to take into account the problem of temporary inconsistency of monetary policy: the central bank must commit itself to achieve the stated goals and strictly follow them,

- central bank independence improves macroeconomic performance: central bank independence allows it to be insulated from political pressures to pursue excessive expansionary policies, as well as to solve the problem of temporary inconsistency in monetary policy,

- public commitments to hold the nominal anchor, which have public confidence, contribute to price stability and sustainable economic growth: they stabilize long-term inflation expectations,

- financial sector imperfections play an essential role in the business cycle: financial instability discourages investment in manufacturing, resulting in a severe economic downturn in the economy $[9 ; 10]$.

Fiscal policy (lat. Fiscus - basket; cash, treasury, finance) - government policy measures the impact on the economy by changing the number of expenditures or revenues of the state budget $[11 ; 12]$. One of the main methods of government intervention in the economy is to reduce fluctuations in economic cycles and ensure a stable financial system in the short term. The main instruments of fiscal policy are taxes, transfers and government procurement of goods and services.
Fiscal policy, in addition to monetary policy, is a vital component of the work of the state as a distributor in the economy. As an instrument of government, fiscal policy has several objectives.

The first goal is to stabilize the level of aggregate demand and, accordingly, gross domestic product. Then the state needs to maintain macroeconomic equilibrium, which can only be successful if all economic resources are effectively used. As a result, together with the smoothing of the parameters of the state budget, the general level of prices will also stabilize. Both aggregate demand and aggregate supply fall under the influence of fiscal policy.

Fiscal policy instruments used to stimulate the economy are as follows:

- reduction of the taxable base;

- tax credit;

- $\quad$ special tax rates;

- reduction of taxes on wages;

- reduction of expenses for joint [with the state] research.

The following conclusions can be drawn:

1. The tax mechanism is the most efficient and effective lever of government regulation. The effectiveness of economic decisions taken at the federal and regional levels largely depends on the successful functioning of the tax system.

2. The tax system is the main component of the general system of economic relations and a potent regulator of economic processes.

3. The efficiency of the functioning of the tax system is achieved through a balanced combination of all its functions, taking into account the interests of the state and taxpayers.

Analysis of general information on revenues of the State Budget of Ukraine(Fig. 2) includes payments to the general and special funds of the state budget. It is revealed that the most significant part of the state budget (over 90\%) is the general fund, whose funds are intended to provide financial resources for general expenditures (i.e., not directed to a specific purpose). Special Fund provides subject-targeted use of budgetary funds (i.e., to finance particular goals).

As we can see from the analysis (Fig. 2), the structure of revenues of the State Budget of Ukraine in 2015-2020 in the essential indicators does not change: the fluctuations are minimal - from $0.3 \%$ to $6.4 \%$, the average $-2.5 \%$.

Consider, for example, the monetary and fiscal policy instruments that the government has introduced by adopting several laws to reduce the financial and economic consequences of the COVID-19 pandemic (Table 1). 


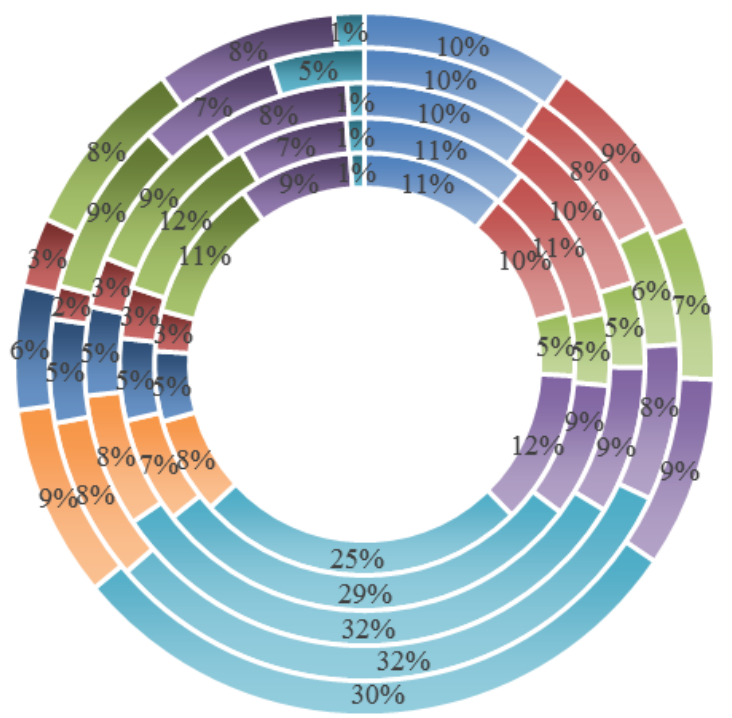

\author{
- income tax \\ - corporate income tax \\ - rent and payment for the use of other natural resources \\ - value added tax on domestic goods \\ - value added tax on imported goods \\ " excise tax on excisable goods produced in Ukraine \\ - excise tax on excisable goods imported into Ukraine \\ - other taxes and fees \\ - income from property and business activities \\ - other non-tax revenues \\ mer
}

Figure 2. The structure of revenues of the State Budget of Ukraine in 2016-2020 by the most critical indicators (according to the Minfin [13])

Table 1. Monetary and fiscal policy instruments to stabilize the effects of the COVID-19 pandemic (according to the Official website of the President of Ukraine [14])

\begin{tabular}{|c|c|c|}
\hline Date & Law & Tools \\
\hline \multirow[t]{2}{*}{ 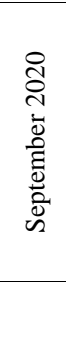 } & $\begin{array}{l}\text { "On Amendments to Certain Legislative } \\
\text { Acts Concerning the Moratorium on } \\
\text { Recovery of Property of Citizens of Ukraine } \\
\text { Provided as Collateral for Foreign Currency } \\
\text { Loans" № 895-IX }\end{array}$ & $\begin{array}{l}\text { The document extends until Apr. 21, 2021, a moratorium on the recovery of these } \\
\text { properties of citizens of Ukraine and prohibits the forced recovery of property } \\
\text { (property rights) if it is used as a permanent residence of the borrower or is the } \\
\text { object of unfinished housing. } \\
\text { It also prohibits the foreclosure of other property (property rights) under mortgage } \\
\text { agreements from persons who have obligations under loans granted to them in } \\
\text { foreign currency and prohibits credit institutions from assigning their rights to the } \\
\text { borrower in favour of another person. }\end{array}$ \\
\hline & $\begin{array}{l}\text { "On Amendments to Certain Laws of } \\
\text { Ukraine on Consumer Lending and the }\end{array}$ & $\begin{array}{l}\text { The document provides for the assignment of credit agreements concluded for up to } \\
\text { one month, and contracts for which the total loan amount does }\end{array}$ \\
\hline \multirow[t]{2}{*}{$\begin{array}{l}\text { ते } \\
\text { ป } \\
\dot{0} \\
\stackrel{0}{0} \\
\stackrel{0}{0}\end{array}$} & $\begin{array}{l}\text { Formation and Circulation of Credit } \\
\text { Histories" № 891-IX }\end{array}$ & $\begin{array}{l}\text { not exceed one minimum wage, to consumer loans and the application of the Law } \\
\text { of Ukraine "On Consumer Lending". This creates the conditions for the proper } \\
\text { regulation of the rapidly growing microcredit market, particularly determining the } \\
\text { requirements for providing and submitting microcredit information to the Credit } \\
\text { Histories Bureau. } \\
\text { The Law also sets the maximum total amount of fines and penalties that may be } \\
\text { charged for breach of obligations under such loans, in an amount not exceeding } \\
\text { twice the amount of the loan received. } \\
\text { It is forbidden to change the interest rate for the consumer's worse and apply fines } \\
\text { and penalties for the same violation. This measure will protect citizens from fines } \\
\text { and penalties, which can be many times higher today than the loan amount. }\end{array}$ \\
\hline & $\begin{array}{l}\text { "On Amendments to Certain Laws of } \\
\text { Ukraine on Social Protection of the } \\
\text { Population for the Period of Quarantine } \\
\text { Established by the Cabinet of Ministers of } \\
\text { Ukraine for the Prevention of the Spread of } \\
\text { Coronavirus Disease (COVID-19)" № } \\
\text { 1030-IX }\end{array}$ & $\begin{array}{l}\text { The law aims to strengthen social protection and support of citizens, particularly in } \\
\text { taking the necessary anti-epidemic measures. } \\
\text { According to the document, the right to receive partial unemployment benefits for } \\
\text { insured persons who lose part of their income because quarantine restrictions are } \\
\text { applied to citizens who receive pensions. } \\
\text { The law regulates specific procedural issues related to the acquisition and } \\
\text { confirmation of unemployment status by a person and the receipt of unemployment } \\
\text { benefits for the period of quarantine. }\end{array}$ \\
\hline
\end{tabular}




\begin{tabular}{|c|c|c|}
\hline \multirow{3}{*}{ 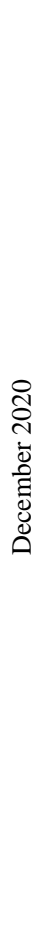 } & $\begin{array}{l}\text { "On social support of insured persons and } \\
\text { business entities for the period of restrictive } \\
\text { anti-epidemic measures introduced to } \\
\text { prevent the spread of acute respiratory } \\
\text { disease COVID-19 caused by coronavirus } \\
\text { SARS-CoV-2 in Ukraine" № 1071-IX }\end{array}$ & $\begin{array}{l}\text { Provides: - provision of one-time financial assistance for UAH 8,000 to employees } \\
\text { who lost part of their wages due to the introduction of quarantine restrictions, and } \\
\text { natural persons-entrepreneurs (PE) who lost part of their income due to quarantine; } \\
\text { - providing one-time financial assistance to companies for payments to employees } \\
\text { to reduce them during the quarantine. This rule is applied to enterprises that (at the } \\
\text { time of entry into force of the law) were forced to reduce or may reduce the working } \\
\text { hours of employees due to downtime due to the introduction of quarantine. The } \\
\text { amount of benefits is calculated in proportion to the reduction of working hours of } \\
\text { the employee but may not exceed } 8 \text { thousand UAH. } \\
\text { - one-time compensation to business entities to reimburse the costs incurred for the } \\
\text { payment of a single contribution (SSC) for compulsory state social insurance. } \\
\text { - extension of licenses to companies for the sale of alcohol for the period of } \\
\text { quarantine, as well as for three months after its expiration. }\end{array}$ \\
\hline & $\begin{array}{l}\text { "On Amendments to the Tax Code of } \\
\text { Ukraine and Other Laws of Ukraine on } \\
\text { Social Support of Taxpayers for the Period } \\
\text { of Restrictive Anti-Epidemic Measures } \\
\text { Introduced to Prevent the Spread of Acute } \\
\text { Respiratory Disease COVID-19 Caused by } \\
\text { SARS-CoV-2 Coronavirus in Ukraine" № } \\
\text { 1072-IX. }\end{array}$ & $\begin{array}{l}\text { The document provides several tax incentives for citizens, small and medium-sized } \\
\text { businesses for the period of possible quarantine: } \\
\text { - the taxpayer's tax debt is written off if the total amount of the taxpayer's debt for all } \\
\text { taxes and fees does not exceed UAH } 3,060 \text {. } \\
\text { - payers of the single tax of the I group are exempted from paying this tax for } \\
\text { December } 2020 \text { and January - May } 2021 \text {. } \\
\text { - until Dec. } 29,2021 \text {, the repayment of the tax debt of taxpayers - individuals, } \\
\text { including self-employed persons, has been postponed, which in total does not } \\
\text { exceed UAH } 6,800 \text {. }\end{array}$ \\
\hline & $\begin{array}{l}\text { "On Amendments to Article } 28 \text { of the Law of } \\
\text { Ukraine" On the State Budget of Ukraine for } \\
\text { 2020" № 1073-IX }\end{array}$ & $\begin{array}{l}\text { The document expands the list of areas in which the Fund can combat the effects of } \\
\text { the coronavirus epidemic. In particular, these funds can be used to finance: } \\
\text { - one-time financial assistance to citizens in case of increased quarantine; } \\
\text { - financial assistance to businesses to save jobs; } \\
\text { - one-time business compensation for the payment of SDRs for employees. }\end{array}$ \\
\hline 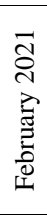 & $\begin{array}{l}\text { "On Amendments to Article } 47-1 \text { of the } \\
\text { Law" On Employment "on the provision of } \\
\text { partial unemployment benefits for the period } \\
\text { of quarantine and/or emergency, established } \\
\text { by the Cabinet of Ministers of Ukraine" № } \\
\text { 1212-IX }\end{array}$ & $\begin{array}{l}\text { It provides partial unemployment benefits for the period of quarantine for insured } \\
\text { persons who have lost part of their income due to restrictive measures related to } \\
\text { combating the spread of COVID-19. This measure will allow Ukrainians to receive } \\
\text { partial unemployment benefits not only for the period of quarantine caused by a } \\
\text { coronavirus in case of other diseases or emergencies on the territory of Ukraine. }\end{array}$ \\
\hline
\end{tabular}

We should note that the proposed measures are effective in the short term since payments are quickly distributed. At the same time, they are effective in returning funds to the economy since the poor have the highest propensity to consume, so fiscal support targeted at them will have the most significant impact.

\section{Results and Discussion}

\subsection{Monetary Policy Improvement Tools}

The most threatening external challenges to the stabilization of the monetary sector (Fig. 3).

The most threatening external challenges to the stabilization of the monetary sector
maintaining low commodity prices;
a gradual increase in US Federal Reserve interest rates and a reduction in the supply of loans to countries with
emerging markets;
slowing down China's economic growth and shifting the focus of domestic policy from investment to
consumption;
the continuation of the armed conflict in eastern Ukraine, the persistence of tensions in the Middle East and the
continuation of the debt crisis in the EU.

Figure 3. External threats to the stabilization of the monetary sector 
We offer the following tools to improve monetary policy:

- providing conditions for the creation of a single, transparent, accessible liquidity platform for stock market participants;

- $\quad$ currency market liberalization;

- $\quad$ improving the external debt management mechanism and introduction of risk-oriented debt policy;

- developing market instruments for hedging currency risks (currency futures and derivatives);

- strengthening the institutional base of foreign investment;

- increasing the efficiency of international financial assistance projects;

- $\quad$ expanding the competitive alternative in cooperation with MFIs and the Asian direction of investment cooperation.

To determine the assessment of the effectiveness of the monetary policy, we propose an algorithm, based on an analysis of the relationship between various socio-economic indicators, taking into account the goals set in the implementation of this policy:

1. To highlight the criterion for assessing the effectiveness of the monetary policy.

2. To identify internal and external factors influencing the goals of the state's monetary policy.

3. To determine the indicator indicators for assessing the effectiveness of the monetary policy.

4. To identify the risks affecting macroeconomic stability.

5. To calculate quantitative indicators or give a qualitative assessment of the criteria for the effectiveness of monetary policy based on a comparative analysis for a certain period.

6. Based on the obtained result, apply an instrument or several instruments of monetary policy;
7. To evaluate the effectiveness of the government's monetary policy following the target.

The critical elements of improving monetary policy in the medium term will be:

1. Continuation of the monetary regime of flexible inflation targeting, based on a floating exchange rate, emphasizes maintaining financial stability and ensuring sustainable economic growth. The consistency of the inflation target and the principles of monetary policy will help stabilize expectations, increase the transparency of the National Bank's actions, which will be reflected in a correct inclusion of inflation risks in the structure of interest rates and their stabilization at a low level. Predictability of inflation and reduction of its volatility will contribute to the deepening of the money market and expand the possibilities of debt financing.

2. Ensuring the stability of the financial sector of Ukraine as a whole and its segments. Achieving the goal of the National Bank to ensure financial stability will be carried out through a set of measures aimed at increasing the resilience of the financial system to systemic risks, adequate assessment and perception of risks by market participants, improving the reliability of critical elements of monetary and foreign exchange market infrastructure.

3. Promoting sustainable economic growth by maintaining a low and stable inflation environment of floating exchange rate. This step will avoid the accumulation of macroeconomic imbalances, increase the margin of safety to external shocks, and reduce real GDP's deviation from its potential level [15].

Theoretical and methodological analysis showed that the main weak point of research is the assessment of the effectiveness of the monetary policy; therefore, we propose the following algorithm (Fig. 4).

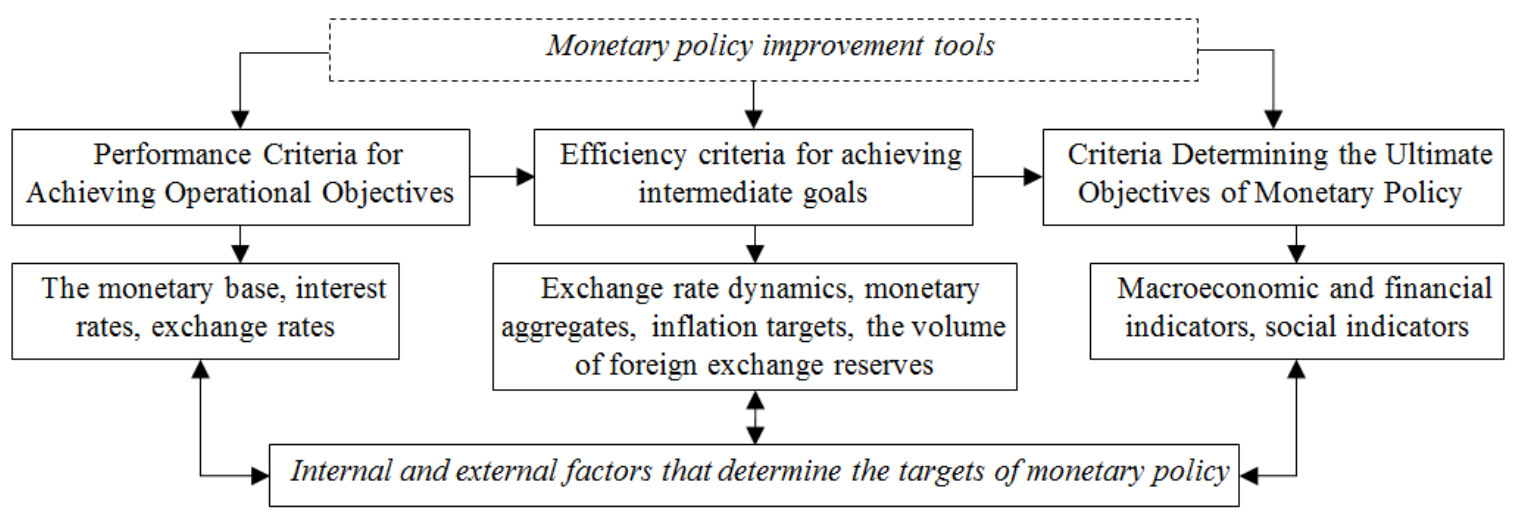

Figure 4. Algorithm for assessing the effectiveness of monetary policy 
In a modern open economy, the criteria for assessing monetary policy should be linked to the country's socio-economic development. Thus, the main criteria for the effectiveness of the monetary policy will be the criteria that contribute to ensuring macroeconomic stability.

For an objective assessment of monetary policy, it is possible to use multidimensional techniques that include a system of indicators. These indicators can be interrelated, while one-aspect methods suffer from an incomplete reflection of the policy pursued by the monetary authorities and consider the influence of a limited number of factors on the effectiveness of the monetary policy.

\subsection{Fiscal Policy Improvement Tools}

Suppose a country is experiencing depression or is in the stage of an economic crisis, which is happening in many countries due to the consequences of a pandemic, including Ukraine. In that case, the state may decide to pursue a stimulating fiscal policy. In this case, the government needs to stimulate either aggregate demand, or supply, or both. For this, other things being equal, the state increases the size of its purchases of goods and services, cuts taxes and increases transfers, if possible. Any of these changes will lead to an increase in aggregate output, which automatically increases aggregate demand and the parameters of the system of national accounts. An incentive fiscal policy leads to a rise in output in most cases.

In March-April 2020, emerging markets, including Ukraine, faced a crisis in health care systems, and they were hit by multiple shocks from declining global demand, a dramatic deterioration in external financing conditions, and falling commodity prices.

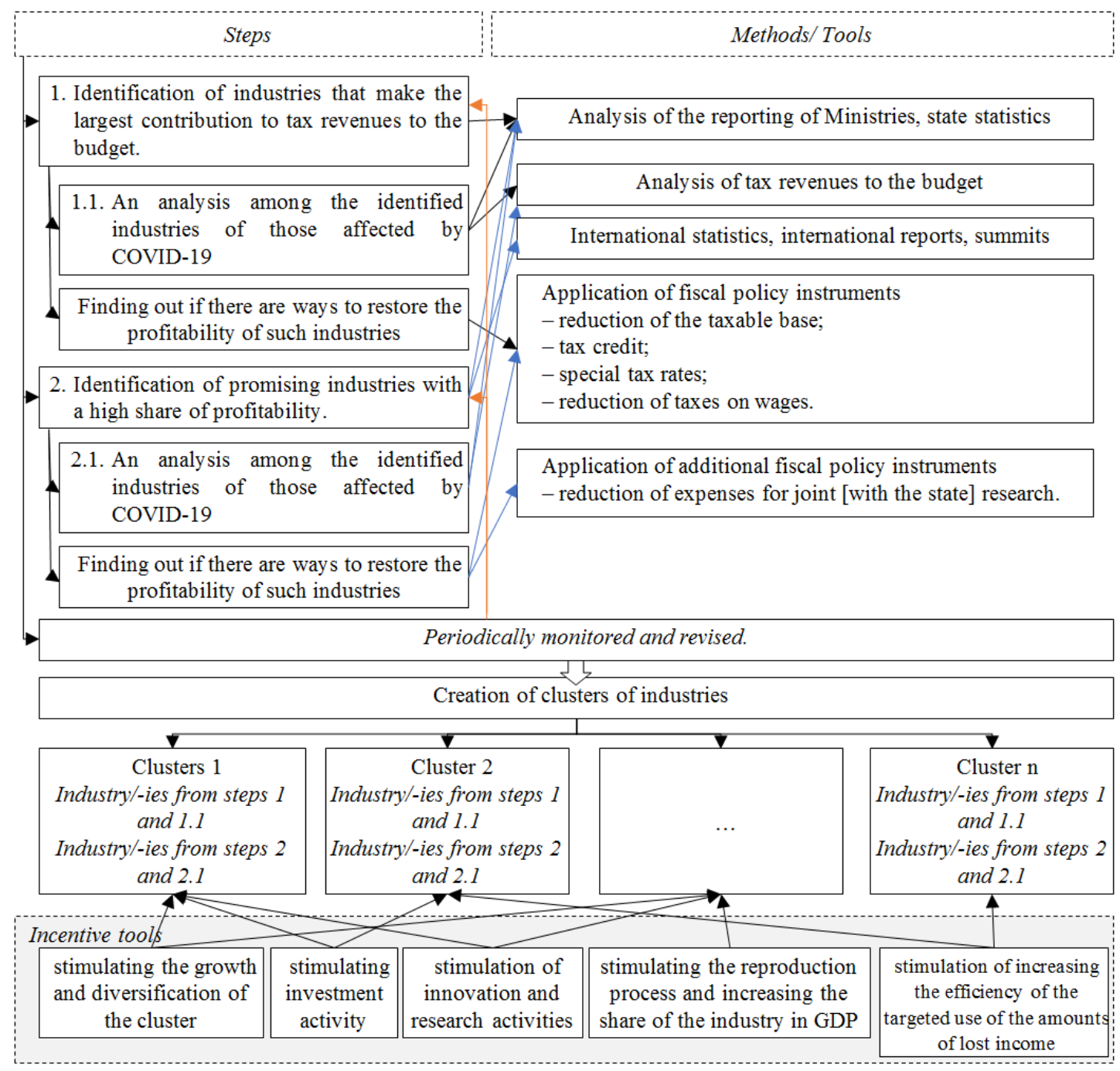

Figure 5. Algorithm for determining targeted support for industries 
According to the IMF forecast, the real GDP of the group of emerging and developing markets will decrease in 2020 by $1 \%$, and the GDP of Ukraine - by $7.7 \%$ [16].

This situation requires the macroeconomic regulators of Ukraine to apply well-structured and balanced fiscal and monetary incentives that would keep the economy from falling sharply and reduce the pressure of cost inflation over the long term.

Budgetary resources limit the use of stimulating fiscal policy. If the budget is in deficit, then, in this case, it becomes impossible to provide state support for the economy since there are no funds for this. But at the same time, it remains possible to provide targeted support for industries or projects. It is in this that we see promising innovative tools, namely, targeted support of industries. We offer the following algorithm (Fig. 5).

It is evident that a decrease in tax rates for all these sectors will make the Ukrainian budget deficit by a relatively significant amount; therefore, three options are proposed for solving the problem of targeted stimulation of the economy:

1. reducing the tax rate for certain types of economic activities that are promising, since they produce high-tech products;

2. abolition of payment of one or more taxes for certain types of economic activity;

3. a combination of the first two options, consisting of the abolition of the tax for some types of economic activity.

The crisis requires the government to use prudent fiscal and monetary incentives to keep the economy falling sharply.

An innovative tool is creating clusters, which will consist of industries that are generating the highest income now and those that are promising and will generate revenue in the future. In the context of each cluster, the initial investment in the development of promising industries will be financed from traditional profitable industries, which in the future may no longer be able to generate income/excess income [17]. During this time, promising industries will develop and move from the inception stage to the growth/maturity stage.

A scientifically based choice of sectors and targets for incentives will increase the degree of effectiveness of sectoral monetary and fiscal incentives.

\section{Conclusions}

The crisis forces the government to resort to prudent fiscal and monetary stimulus to avoid a sharp downturn in the economy.

When applying the instruments of monetary and fiscal policy, as well as when assessing their effectiveness, it should be borne in mind that some types of government measures may not stimulate economic growth, but slow it down, or cause it to slow down in the future. Using modern tax incentive tools is not a perfect way to achieve economic growth. Excessive use of tax incentives and preferences reduces the neutrality of the tax system, increases the costs of tax administration, and, as a consequence, reduces the efficiency of the tax system, differentiates the tax burden between different industries and categories of taxpayers, and, consequently, reduces the fairness of the system, complicates the structure of taxes and system as a whole.

\section{REFERENCES}

[1] National Bank of Ukraine. Financial Stability Report. December 2020. https://bank.gov.ua/admin_uploads/article/ FSR_2020-H2_eng.pdf?v=4 (accessed Jun. 26, 2021).

[2] Ponomarenko T., Prokopenko O., Kuzmenko H., Kaminska T., Luchyk M., "Banking security of Ukraine: current state and ways to improve," Banks and Bank Systems, vol. 13, no. 2, pp. 77-88, 2018. DOI: 10.21511/bbs.13(2).2018.07

[3] United Nations. Assessment of the Socio-Economic Impact of Covid-19 in Ukraine. https://ukraine.un.org/sites/default/f iles/2020-12/UN\%20SEIA\%20Report\%202020\%20\%281\% 29.pdf (accessed Jun. 26, 2021).

[4] Sagaidak M., "Basic principles of building relationships with frontline personnel within internal marketing system," Actual Problems of Economics, vol. 159, no. 9, pp. 224-231, 2014.

[5] Kardar S., "Monetary and Fiscal Policies," The lahore journal of economics, vol. 12, Special Edition, 2007. DOI: 10.35536/lje.2007.v12.isp.a4

[6] Danylyshyn, B., "Do not repeat mistakes", LB.ua, https://lb.ua/blog/bogdan_danylysyn/479007_povtoryuvati_ pomilok.html (accessed Jun. 26, 2021).

[7] Moiseev S., "Monetary policy: theory and practice," in Moscow Financial and Industrial Academy, $1^{\text {st }}$ ed, 2010.

[8] Özker A., "Changes in Investment Options in OECD Countries and Its Relationship with Analytical Tax Burden," Universal Journal of Accounting and Finance, vol. 9, no. 3, pp. 295-305, 2021. DOI: 10.13189/ujaf.2021.090303.

[9] Ishak A., Ali M., "Factors Influencing Intention to Participate in Tax Evasion: Individual Perspectives," Universal Journal of Accounting and Finance, vol. 8, no. 4, pp. 103-114, 2020. DOI: $10.13189 /$ ujaf.2020.080403.

[10] Mishkin F., "Will monetary policy become more of a science?" in Monetary Policy Over Fifty Years: Experiences and Lessons, $1^{\text {st }}$ ed, Routledge, 2009, pp. 81-107.

[11] Cole H., "Optimal Monetary and Fiscal Policy," In Monetary and Fiscal Policy through a DSGE Lens, 2020. DOI: 10.1093/oso/9780190076030.003.0021

[12] Han Z., Tan F., Wu J., "Learning from Monetary and Fiscal Policy," SSRN Electronic Journal, pp. 1-68, 2021. DOI: 10.2139/ssrn.3726905 
[13] Minfin.https://index.minfin.com.ua/ua/finance/budget/gov/i ncome/2020/ (accessed Jun. 26, 2021).

[14] President of Ukraine. Volodymyr Zelenskyy. Official website https://www.president.gov.ua/en (accessed Jun. 26, 2021).

[15] Danylyshyn B., "On the question of the basic principles of monetary policy for 2021 and the medium term", LB.ua, https://lb.ua/blog/bogdan_danylysyn/463843_pitannya_pro_ osnovni_zasadi.html (accessed Jun. 26, 2021).
[16] Danylyshyn B., "What should be the economic therapy from the National Bank", Ekonomichna pravda, https://www.epra vda.com.ua/columns/2020/04/28/659916/ (accessed Jun. 26, 2021).

[17] Kovalenko V., Kuznetsova L., Sergeeva E., Todorova N., Mylashko O., Tej J., "Cluster approach to banking supervision with reference to bank risk profile," Economic Annals-XXI, vol. 177, no. 5-6, pp. 82-91, 2019. DOI: 10.21003/ea.V177-07 